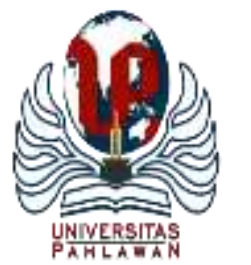

Edukatif : Jurnal Ilmu Pendidikan Volume 3 Nomor 6 Tahun 2021 Halm 4483 - 4492

EDUKATIF: JURNAL ILMU PENDIDIKAN

Research \& Learning in Education

https:/ledukatif.org/index.php/edukatif/index

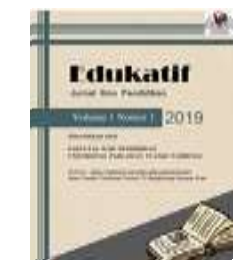

\title{
Potret Model Pembelajaran Daring Online terhadap Perkuliahan Praktikum Masa Pandemi Covid-19
}

\author{
Srinatalia Silaen ${ }^{1 凶}$, Welmar Olfan Basten Barat ${ }^{2}$ \\ Universitas HKBP Nommensen Pematangsiantar, Indonesia ${ }^{1}$ \\ Universitas HKBP Nommensen Pematangsiantar, Indonesia ${ }^{2}$ \\ E-mail : srinatalia.silaen92@gmail.com ${ }^{1}$, olfan_basten_barat@yahoo.com $^{2}$
}

\begin{abstract}
Abstrak
Dalam kurun waktu setahun belakangan, kita semua menghadapi wabah pandemi dari virus yang membuat seluruh manusia dan mobilitasnya terganggu, termasuk aspek pendidikan, kesehatan, ekonomi, industri bahkan sosial - budaya. Terlebih kita selaku tenaga pendidik dan menyentuh langsung dengan dunia pembelajaran bagi mahasiswa, turut terkena dampak dalam pengajaran yang awalnya tatap muka beralih ke sistem pembelajaran daring, oleh karena itu tujuan dari dilakukannya penelitian ini mengarah untuk proses perkuliahan secara virtual dan sistem secara online. Pada prosesnya, metode yang digunakan bagi para pengajar khususnya dosen adalah virtual dan online yang bisa membantu proses pengajaran terutama mata kuliah praktikum di Program studi Biologi. Adapun hasil dari dilakukannya korespondensi dari tahap wawancara antara dosen dan mahasiswa di semester VI, terlebih di pembelajaran praktikum yang sebelumnya dilakukan di laboratorium dan dimasa pandemi menjadi virtual. Pembelajaran daring menjadi pilihan efektif bagi para dosen dan mahasiswa dalam membantu program pemerintah belajar dari rumah (Daring) dan mengurangi mobilitas seperti sedia kala, dan kita berharap agar pandemi segera berlalu dan covid-19 menjadi masalah kita bersama demi mengurangi dampak dari wabah Covid-19 ini.
\end{abstract}

Kata Kunci: Model Pembelajaran, pembelajaran jarak jauh, covid-19.

\begin{abstract}
In the past year, we have all faced pandemic outbreaks from viruses that have disrupted all humans and their mobility, including aspects of education, health, economy, industry and even social - culture. Moreover, we as educators and touch directly with the world of learning for students, also affected in teaching that was initially face-to-face switching to online learning systems, therefore the purpose of this research leads to the virtual lecture process and online system. In the process, the methods used for teachers, especially lecturers, are virtual and online that can help the teaching process, especially practicum courses in biology study programs. As for the results of correspondence from the interview stage between lecturers and students in semester VI, especially in practicum learning previously conducted in the laboratory and in the pandemic period became virtual. Online learning is an effective option for lecturers and students in helping government programs learn from home (Online) and reduce mobility as usual, and we hope that the pandemic will soon pass and Covid-19 becomes our common problem to reduce the impact of the Covid-19 outbreak.
\end{abstract}

Keywords: Learning Model, distance learning, covid-19.

Copyright (c) 2021 Aulia Diana Devi, Subiyantoro

$\square$ Corresponding author

Email : srinatalia.silaen92@gmail.com

DOI $\quad$ : https://doi.org/10.31004/edukatif.v3i6.1490

ISSN 2656-8063 (Media Cetak)

ISSN 2656-8071 (Media Online) 
4484 Potret Model Pembelajaran Daring Online terhadap Perkuliahan Praktikum Masa Pandemi Covid-19Aulia Diana Devi, Subiyantoro

DOI : https://doi.org/10.31004/edukatif.v3i6.1490

\section{PENDAHULUAN}

Wabah corona virus disease 2019 (Covid-19) yang telah melanda 215 negara di dunia, memberikan tantangan tersendiri bagi lembaga pendidikan, khususnya Perguruan Tinggi. Untuk melawan Covid-19 Pemerintah telah melarang untuk berkerumun, pembatasan sosial (social distancing) dan menjaga jarak fisik (physical distancing), memakai masker dan selalu cucitangan. Melalui Kementerian Pendidikan dan Kebudayaan Pemerintah telah melarang perguruan tinggi untuk melaksanakan perkuliahan tatap muka (konvensional) dan memerintahkan untuk menyelenggarakan perkuliahan atau pembelajaran secara daring (Indrawati, 2020). Perguruan tinggi dituntun untuk dapat menyelenggarakan pembelajaran secara daring atau on line (Firman \& Rahayu, 2020). Tidak sedikit universitas dengan cepat merespon intruksi pemerintah, tidak terkecuali Universitas HKBP Nommensen Pematangsiantar (UHKBPNP) dengan mengeluarkan surat instruksi tentang pencegahan penyebaran Corona Virus Diesease (Covid-19) di lingkungan Universitas HKBP Nommensen Pematangsiantar. Di surat edaran itu ada 10 poin dan salah satunya adalah anjuran untuk menerapkan pembelajaran daring (Yandwiputra, 2020). Ada sekitar 65 perguruan tinggi di Indonesia yang telah melaksanakan pembelajaran daring dalam mengantisipasi penyebaran Covid-19. Jamaluddin et al., (2020) menyatakan bahwa pembelajaran daring memiliki kekuatan, tantangan dan hambatan tersendiri.

Untuk mencegah penyebaran Covid-19, WHO memberikan himbauan untuk menghentikan acara-acara yang dapat menyebabkan massa berkerumun. Maka dari itu, pembelajaran tatap muka yang mengumpulkan banyak mahasiswa di dalam kelas ditinjau ulang pelaksanaanya. Perkuliahan harus diselenggarakan dengan skenario yang mampu mencegah berhubungan secara fisik antara mahasiswa dengan dosen maupun mahassiswa dengan mahasiswa. Menurut (Sadikin \& Hamidah, 2020) penggunaan teknologi digital dapat memungkinkan mahasiswa dan dosen melaksanakan proses pembelajaran walaupun mereka ditempat yang berbeda.Bentuk perkuliahan yang dapat dijadikan solusi dalam masa pandemi covid-19 adalah pembelajaran daring.

Pembelajaran daring merupakan pembelajaran yang menggunakan jaringan internet dengan aksesibilitas, konektivitas, fleksibilitas, dan kemampuan untuk memunculkan berbagai jenis interaksi pembelajaran. Penelitian yang dikakukan oleh Agustina,(2020) menunjukkan bahwa penggunaan internet dan teknologi multimedia mampu merombak cara penyampaian pengetahuan dan dapat menjadi alternatif pembelajaran yang dilaksanakan dalam kelas tradisional. Pembelajaran daring adalah pembelajaran yang mampu mempertemukan mahasiswa dan dosen untuk melaksanakan interaksi pembelajaran dengan bantuan internet (Anggereini, 2017). Pada tataran pelaksanaanya pembelajaran daring memerlukan dukungan perangkat-perangkat mobile seperti smartphone atau telepon adroid, laptop, komputer, tablet, dan iphone yang dapat dipergunakan untuk mengakses informasi kapan saja dan dimana saja (Gikas \& Grant, 2013). Perguruan tinggi pada masa WFH perlu melaksanakan penguatan pembelajaran secara daring. Pembelajaran secara daring telah menjadi tuntutan dunia pendidikan sejak beberapa tahun terakhir (He et al., 2014). Pembelajaran daring dibutuhkan dalam pembelajaran di era revolusi industri 4.0 (Pangondian et al., 2019).

Penggunaan teknologi mobile mempunyai sumbangan besar dalam lembaga pendidikan, termasuk di dalamnya adalah pencapaian tujuan pembelajaran jarak jauh (Korucu \& Alkan, 2011). Berbagai media juga dapat digunakan untuk mendukung pelaksanaan pembelajaran secara daring. Misalnya kelas-kelas virtual menggunakan layanan Google Classroom, Edmodo, dan Schoology Enriquez, (2014); Iftakhar, (2016), dan applikasi pesan instan seperti WhatsApp (So, 2016). Pembelajaran secara daring bahkan dapat dilakukan melalui media sosial seperti Facebook dan Instagram Rhamadani et al., (2021). Pembelajaran daring menghubungkan peserta didik dengan sumber belajarnya (database, pakar/instruktur, perpustakaan) yang secara fisik terpisah atau bahkan berjauhan namun dapat saling berkomunikasi, berinteraksi atau berkolaborasi (secara langsung/synchronous dan secara tidak langsung/asynchronous). 
4485 Potret Model Pembelajaran Daring Online terhadap Perkuliahan Praktikum Masa Pandemi Covid-19Aulia Diana Devi, Subiyantoro

DOI

Komunikasi terjalin kurang lancar tersebut menyebabkan materi menjadi sulit dipahami terutama mata kuliah praktikum. Hal tersebut ditambah dengan ungkapan salah satu informan yang mengatakan bahwa dosen lebih fokus memberikan tugas ketimbang materi. Selain itu, letak dan kondisi geografis tempat tinggal mahasiswa yang berbeda -beda terkadang membuat koneksi internet buruk sehingga mengganggu audio dan tampilan/visualisasi materi ajar pada layar gawai/laptop. Selain itu, pembelajaran daring dinilai oleh sebagian informan kurang efektif karena beberapa aplikasi yang koneksinya lancar terkadang boros kuota. Hasil belajar mahasiswa bervariasi, mulai dari kurang memuaskan, cukup hingga baik. Dua orang mahasiswa mengatakan bahwa hasil belajarnya kurang memuaskan karena materi yang dipahami lebih sedikit daripada pembelajaran tatap muka dikelas. Keuntungan penggunaan pembelajaran online adalah pembelajaran bersifat mandiri dan interaktivitas yang tinggi, mampu meningkatkan tingkat ingatan, memberikan lebih banyak pengalaman belajar, dengan teks, audio, video dan animasi yang semuanya digunakan untuk menyampaikan informasi, dan juga memberikan kemudahan menyampaikan, memperbarui isi, mengunduh, para siswa juga bisa mengirim email kepada siswa lain, mengirim komentar pada forum diskusi, memakai ruang chat, hingga link video conference untuk berkomunikasi langsung. Berdasarkan Surat Edaran (SE) yang dikeluarkan pemerintah pada 18 Maret 2020, maka segala kegiatan didalam dan diluar ruangan di semua sektor sementara waktu ditunda demi mengurangi penyebaran corona terutama pada bidang pendidikan. Pada tanggal 24 maret 2020 Menteri Pendidikan dan Kebudayaan Republik Indonesia mengeluarkan Surat Edaran Nomor 4 Tahun 2020 Tentang Pelaksanaan Kebijakan Pendidikan Dalam Masa Darurat Penyebaran Covid-19. Surat Edaran tersebut menjelaskan bahwa proses belajar dilaksanakan di rumah melalui pembelajaran daring/jarak jauh dilaksanakan untuk memberikan pengalaman belajar yang bermakna bagi siswa.

Tujuan dari penelitian ini adalah untuk memperoleh gambaran pembelajaran daring di Program studi pendidikan biologi FKIP Universitas HKBP Nommensen Pematangsiantar semasa pandemi covid-19. Pelaksanaan pembelajaran daring di jurusan pendidikan biologi berjalan dengan lancar, namun dirasakan sebagian besar dosen dan mahasiswa kurang ideal dibandingkan pembelajaran tatap muka secara konvensional. Komunikasi yang terkadang dilakukan secara tidak serentak membuat sebagian mahasiswa merasa kesulitan untuk mengajukan pertanyaan pada saat proses pembelajaran berlangsung. Belajar di rumah dapat difokuskan pada pendidikan kecakapan hidup antara lain mengenai pandemi Covid-19. Universitas HKBP Nommensen Pematangsiantar merupakan salah satu perguruan tinggi yang menerapakan kebijakan tersebut. Kebijakan yang dibuat oleh pimpinan Universitas HKBP Nommensen Pematangsiantar mengenai pembelajaran daring dilakukan agar mengurangi grafik penyebaran Covid-19 yang semakin hari semakin bertambah. Berdasarkan hal tersebut peneliti ingin mengetahui dampak Covid-19 terhadap pembelajaran online Pendidikan Biologi FKIP di Universitas HKBP Nommensen Pematangsiantar.

\section{METODE PENELITIAN}

Penelitian ini dilakukan dengan metode deskriptif dengan pendekatan kualitatif dan studi literatur. Penelitian kualitatif digunakan dengan merujuk kepada pendapat (Sugiyono, 2010) bahwa metode penelitian kualitatif merupakan metode penelitian naturalistic karena penelitiannya dilakukan pada kondisi yang alamiah (natural setting), dan data yang terkumpul dianalisis secara kualitatif. Kualitatif dipandang relevan untuk menggambarkan kondisi yang terjadi pada saat ini dan menjadi latar belakang penelitian yaitu pembelajaran daring pada masa pandemi. Jenis data yang dikumpulkan merupakan data sekunder berupa hasil-hasil penelitian dari berbagai artikel, sumber pustaka dan dokumen serta kalimat penjabaran dari jawaban subjek penelitian yang dilakukan dengan wawancara. Subjek dan objek dalam penelitian ini adalah mahasiswa dan dosen di jurusan pendidikan biologi Universitas HKBP Nommensen Pematangsiantar dengan teknik snowball throwing. Instrumen penelitian terdiri dari pedoman wawancara yang dilakukan secara online melalui aplikasi WhatsApp. 
4486 Potret Model Pembelajaran Daring Online terhadap Perkuliahan Praktikum Masa Pandemi Covid-19Aulia Diana Devi, Subiyantoro

DOI

Jenis penelitian yang digunakan adalah penelitian kualitatif. Tujuan penelitian ini adalah menggambarkan pembelajaran daring yang diselenggarakan di Prodi Pendidikan Biologi FKIP Universitas HKBP Nommensen Pematangsiantar sebagai upaya dalam menekan mata rantai penyebaran Covid-19 di lingkungan perguruan tinggi. Pembelajaran daring yang dimaksud dalam penelitian ini adalah pembelajaran yang menggunakan media-media pembelajaran yang dapat diakeses menggunakan platform yang ada secara online seperti zoom meeting, WhatsApp, youtube, google classroom, cisco webex, zenius, kelas pintar, quipper dan lain sebagainya yang bisa di download aplikasinya di android, dan laptop bapak/ibu dosen dalam proses pembelajaran daring di era pandemi saat ini.

\section{HASIL DAN PEMBAHASAN PENELITIAN}

\section{Hasil}

Pembelajaran pada masa pandemi Covid-19 di jurusan pendidikan Biologi Universitas HKBP Nommensen Pematangsiantar seluruhnya dilaksanakan secara daring baik syncronous (langsung) maupun asyncronous (tidak langsung). Melalui pembelajaran daring mahasiswa bisa belajar seperti biasanya dan tidak ketinggalan materi perkuliahan, karena waktu yang dirasakan lebih fleksibel. Namun pembelajaran daringtidak disambut baik sepenuhnya oleh mahasiswa, karena ada sebagian mahasiswa yang menganggap bahwa pembelajaran daring ini memiliki tingkat kesulitan yang lebih dibandingkan dengan pembelajaran konvensional. Hal tersebut ditambah dengan tuntutan terhadap kuota internet yang harus selalu tersedia. Ini merupakan kesulitan terbesar yang dialami mahasiswa. Kendala lain yang dihadapi adalah buruknya koneksi internet di daerah tempat tinggal mahasiswa, dan ketersediaan perangkat pembelajaran seperti laptop. Mahasiswa merasakan bahwa tingkat pemahaman materi relatif lebih baik pada proses perkuliahan tatap muka secara langsung didalam kelas. Kendala lainnya adalah tidak semua dosen dan mahasiswa siap mengoperasikan sistem pembelajaran daring dengan cepat, termasuk juga mempersiapkan bahan perkuliahan secara digital.

Penelitian ini dilakukan terhadap dosen dan mahasiswa melalui wawancara dengan menggunakan Whatsapp. Informan yang pertama merupaka mahasiswa semester 6 yang sedang mengambil mata kuliah Praktikum di Program Studi Pendidikan Biologi.

Berikut kutipan wawancara dengan informan pertama:

Tanya : Bagaimanakah pelaksanaan kegiatan pembelajaran di Jurusan Pendidikan biologi UHKBPNP setelah terjadinya pandemi Covid-19?

Jawab : Tetap berjalan lancar dengan via daring dan secara total berupa online

Tanya : Jenis aplikasi apa saja yang dipergunakan dosen pada saat melaksanakan kegiatan pembelajaran online?

Jawab : class unsil, google meet, zoom, Whatsapp, telegram, google classroom, youtube, facebook, messenger.

Tanya : Bagaimanakah pelaksanaan pembelajaran onlinedengan menggunakan aplikasi tersebut?

Jawab : Berjalan lancar namun adakalanya terdapat kendala karena kondisi daerah yg berbeda membuat jaringan sinyalpun berbeda, kondisi gawai atau laptop yg mendukung tidaknya serta kuota yg harus selalu terisi.

Tanya : Bagaimanakah hasil belajar mahasiswa pada saat pembelajaran dengan menggunakan media online? Jawab : Menurut saya bagus adakalanya agar terbiasa karena proses pembelajaran harus selalu terjadi walaupun dengan cara dan media apapun namun persiapan harus selalu disiapkan dan meminimalisir kekurangan. 
4487 Potret Model Pembelajaran Daring Online terhadap Perkuliahan Praktikum Masa Pandemi Covid-19Aulia Diana Devi, Subiyantoro

DOI : https://doi.org/10.31004/edukatif.v3i6.1490

Tanya : Menurut anda efektifkah pembelajaran online?

Jawab :Cukup efektif

Tanya : Kendala apakah yang anda hadapi dalam pembelajaran dengan menggunaan media daring?

Jawab : Kuota yg harus di beli, tugas yang selalu menumpuk, karena keadaan dirumah berbeda sehingga harus terbagi fokus, pemahaman tersampaikan namun kurang begitu langsung sehingga harus mereview secara mandiri

Wawancara kedua dilakukan terhadap informan yang merupakan dosen di jurusan pendidikan biologi. Berdasarkan hasil wawancara dapat diketahui bahwa sebelum masa pandemi Covid-19, proses pembelajaran pada mata kuliah yang diampunya sudah dilakukan dengan model blended dengan proporsi $40 \%$ tatap muka didalam kelas dan 60\% dilakukan dengan menggunakan platform google classroom. Setelah masa pandemi,pembelajaran seluruhnya dilakukan secara online.

Aplikasi utama yang digunakan adalah google calssroom, ditambah youtube dan flatform lain untuk membuat kuis seperti quiz. Menurutnya, kondisi pembelajaran online tidak se-ideal pembelajaran tatap muka. Koneksi internet yang tidak stabil dan motivasi belajar mahasiswa menjadi salah satu kendala dalam proses pembelajaran daring. Namun secara keseluruhan, mayoritas mahasiswa menjadi lebih aktif dalam proses perkuliahan. Keunggulan model pembelajaran daring dibandingkan model konvensional adalah waktu perkuliahan yang lebih fleksibel. Walaupun tingkat efektifitasnya belum dapat diukur secara pasti, namun pembelajaran daring dirasakan efektif dilihat dari perolehan nilai mahasiswa.

Hasil belajar mahasiswa ditandai oleh capaian 60\% mahasiswa untuk mendapatkan nilai B (Baik). Kendala yang dihadapi selain akses internet yang tidak sama disetiap tempat, adalah motivasi intrinsik dalam diri mahasiswa. Informan ketiga yaitu mahasiswa semester 4 yang sedang mengambil mata kuliah Praktikum Biologi.

Hasil wawancara memperlihatkan bahwa terdapat perbedaan pendapat antara informan satu dengan informan yang lainnya terkait pertanyaan yang disampaikan oleh peneliti mengenai aktifitas pembelajaran pada masa pandemi Covid-19.

Berikut cuplikan wawancara peneliti dengan informan kedua :

Tanya : Bagaimanakah pelaksanaan kegiatan pembelajaran di Jurusan Pendidikan Biologi Universitas HKBP Nommensen Pematangsiantar setelah terjadinya pandemi Covid-19?

Jawab : Pembelajaran secara Daring

Tanya : Jenis aplikasi apa saja yang dipergunakan dosen pada saat melaksanakan kegiatan pembelajaran online?

Jawab : Zoom,Google Classroom, grup WA,Telegram, dan Vclass unsil.

Tanya : Bagaimanakah pelaksanaan pembelajaran online dengan menggunakan aplikasi tersebut?

Jawab : Kurang efektif, penyampaian terbatas dan terfokus pada tugas bukan pada materi.

Tanya : Bagaimanakah hasil belajar mahasiswa pada saat pengamatan pada praktikum dengan menggunakan media online?

Jawab : Kurang efektif, karena kurangnya interaksi antara mahasiswa dan dosen pada pengamatan

Tanya : Menurut anda efektifkah pembelajaran online?

Jawab : Pembelajaran online ini kurang efektif karena adanya beberapa kendala. Materi yang didapatkan kurang dapat dipahami terlebih pada mata kuliah praktikum. Apalagi dengan banyaknya mahasiswa menyebabkan kurang terkontrolnya pembelajaran dan pengawasan.

Tanya : Kendala apakah yang anda hadapi dalam pembelajaran dengan menggunaan media daring?

Jawab : Kuota, jaringan, kendala dalam aplikasi, perubahan jadwal mendadak. Wawancara selanjutnya dilakukan kembali terhadap dosen. 
4488 Potret Model Pembelajaran Daring Online terhadap Perkuliahan Praktikum Masa Pandemi Covid-19Aulia Diana Devi, Subiyantoro

DOI

Menurut hasil wawancara melalui percakapan langsung diketahui beberapa informasi terkait pembelajaran daring, yaitu : Pada masa pandemi Covid-19 pembelajaran dilakukan secara daring mengingat adanya kebijakan lockdown karena harus memperhatikan protokol kesehatan. Media yang digunakan adalah vclass unsil dan google classroom. Menurutnya, pelaksanaan pembelajaran online berlangsung lancar namun ada beberapa kendala karena diantaranya karena sinyal, kuota internet yang kurang memadai. Hasil belajar dapat diukur dari tingkat kehadiran siswa, jumlah tugas yang dikumpulkan dan nilai UTS dan UAS. Pembelajaran daring dianggap efektif karena kondisi pandemi tidak memungkinkan pembelajran dalam bentuk tatap muka secara langsung. Kendala yang dihadapi antara lain sinyal, dan kuota internet yang masih belum memadai untuk semua mahasiswa.

\section{Mahasiswa memiliki fasilitas yang memadai untuk melaksanakan pembelajaran daring}

Peningkatan dalam penggunaan internet di Indoensia dipengaruhi oleh perkembangan teknologi informasi dan komunikasi Rahadian, (2017). Pada tahun 2018 ada 62,41\% orang penduduk Indonesia telah memiliki telepon seluler dan 20,05\% rumah tangga telah memiliki komputer dirumahnya (Fatmawati, 2020). Data ini relevan dengan hasil riset yang memaparkan bahwa walaupun ada mahasiswa yang belum memiliki laptop, akan tetapihampir seluruh mahasiswa telah mempunyai smartphone. Survei yang telah dilakukan melaporkan bahwa 54 orang mempunyai smartphone dan laptop dan 42 orang mempunyai smartphone saja. Penggunaan smartphone dan laptop dalam pembelajaran daring dapat meningkatkan hasil belajar peserta didik. Pangondian et al., (2019) menyatakan banyak kelebihan penggunaan teknologi informasi dan komunikasi dalam pelaksanaan pembelajaran daring diantaranya adalah tidak terikat ruang dan waktu.

Penelitian telah banyak dilakukan yang meneliti tentang penggunaan gawai serpti smartphone dan laptop dalam pembelajaran. Kemampuan smartphone dan laptop dalam mengakses internet membantu mahasiswa untuk mengikuti pembelajaran daring Kay \& Lauricella, (2011); Gikas \& Grant, (2013); Chan et al., (2015); Li et al.,( 2016) Penggunaan pembelajaran daring menggunakan zoom cloud meeting memiliki kelebihan dapat berinteraksi langsung antara mahasiswa dan dosen serta bahan ajar tetapi memiliki kelemahan boros kuata dan kurang efektif apabila lebih dari 20 peserta didik (Naserly, M. K.,2020). Lebih lanjut, tantangan pembelajaran daring adalah ketersediaan layanan internet. Sebagian mahasiswa mengakses internet menggunakan layanan selular, dan sebagian kecil menggunakan layanan WiFi. Ketika kebijakan pembelajaran daring diterapkan di Universitas Jambi, mahasiswa pulang kampung. Mereka mengalami kesulitan sinyal selular ketika di daerah masing-masing, jikapun ada sinyal yang didapatkan sangat lemah. Hal ini menjadi tantangan tersendiri dalam penerapan pembelajaran daring di Universitas Jambi. Pembelajaran daring memiliki kelemahan ketika layanan internet lemah, dan intruksi dosen yang kurang dipahami oleh mahasiswa (Yunitasari \& Hanifah, 2020). Tantang lain yang dihadapi adalah kendala dalam pembiayaan pembelajaran daring.

Mahasiswa mengungkapkan bahwa untuk mengikuti pembelajaran daring, mereka harus mengeluarkan biaya cukup mahal untuk membeli kuota data internet. Menurut mereka, pembelajaran dalam bentuk konferensi video telah menghabiskan banyak kuota data, sementara diskusi online melalui applikasi pesan instan tidak membutuhkan banyak kuota. Rata-rata mahasiswa menghabiskan dana Rp. 100.000 sampai Rp. 200.000 per minggu, tergantung provider seluler yang digunakan. Penggunaan pembelajaran daring menggunakan konferensi video membutuhkan biaya yang cukup mahal (Naserly, 2020). Walaupun penggunaan gawai dapat mendukung pembelajaran daring, tetapi ada dampak negatif yang perlu mendapat perhatian dan diantisipasi yaitu penggunaan gawai yang berlebihan. Mereka mengakui bahwa selain untuk pembelajaran, mahasiswa juga menggunakan gawai untuk media sosial dan menonton youtube.

Mahasiswa mengakses media sosial dalam rangka ekspresi diri, membangun jejaring pertemanan dan opini Kim et al., (2016). Sangat disayangkan, banyak orang kecanduang gawai akibat menggunakannya secara berlebihan. Perlu dikhawatirkan masuknya informasi yang menyesatkan dan tidak perhatian selama belajar 
4489 Potret Model Pembelajaran Daring Online terhadap Perkuliahan Praktikum Masa Pandemi Covid-19Aulia Diana Devi, Subiyantoro

DOI

akibat bermain media sosial (Siddiqui \& Singh, 2016). Selain itu, peserta didik yang kecanduan gawai memiliki masalah akademik dan sosial. Peserta didik yang memiliki kecanduan gadget memiliki masalah emosional dan perilaku (Asif \& Rahmadi, 2017).

\section{Efektivitas Pembelajaran daring.}

Pembelajaran daring yang dilaksanakan di Program Studi Pendidikan Biologi FKIP Universitas Jambi dalam upaya memutus mata rantai penyebaran Covid- 19 menggunakan aplikasi-aplikasi pembelajaran yang dapat diakses dengan jaringan BIODIK: Jurnal Ilmiah Pendidikan Biologi Vol.06, No. 02 (2020) (Silaen \& Mulya, 2018). Secara keseluruhan, mahasiswa puas dengan pembelajaran yang fleksibel. Dengan pembelajaran daring, mahasiswa tidak terkendala waktu dan tempat dimana mereka dapat mengikuti perkuliahan dari rumah masing-masing maupun dari tempat dimana saja. Dengan pembelajaran daring, dosen memberikan perkuliahan melalui kelas-kelas virtual yang dapat diakses dimana pun dan kapan pun tidak terikat ruang dan waktu. Kondisi ini membuat mahasiswa dapat secara bebas memilih mata kuliah yang dikuti dan tugas mana yang harus dikerjakan lebih dahulu. Penelitian Sahliah, (2021) menginformasikan bahwa fleksibilitas waktu, metode pembelajaran, dan tempat dalam pembelajaran daring berpengaruh terhadap kepuasan mahasiswa terhadap pembelajaran.

Ditemukan hasil penelitian yang unik dari penelitian ini yaitu mahasiswa merasa lebih nyaman dalam mengemukakan gagasan dan pertanyaan dalam pembelajaran daring. Mengikuti pembelajaran dari rumah membuat mereka tidak merasakan tekanan psikologis dari teman sebaya yang biasa mereka alami ketika mengikuti pembelajaran tatap muka. Ketidakhadiran dosen secara langsung atau fisik juga menyebabkan mahasiswa merasa tidak canggung dalam mengutarakan gagasan.Ketiadaaan penghambat fisik serta batasan ruang dan waktu menyebabkan peserta didik lebih nyaman dalam berkomunikasi. Lebih lanjut, pembelajaran secara daring menghilangkan rasa cangung yang pada akhirnya membuat mahasiswa menjadi berani berekpresi dalam bertanya dan mengutarakan ide secara bebas. Pembelajaran daring juga memiliki kelebihan mampu menumbuhkan kemandirian belajar (self regulated learning).

\section{PEMBAHASAN}

Pembelajaran daring memiliki tantangan khusus, lokasi mahasiswa dan dosen yang terpisah saat melaksanakan menyebabkan dosen tidak dapat mengawasi secara langsung kegiatan mahasiswa selama proses pembelajaran. Tidak ada jaminan bahwa mahasiswa sunguh-sungguh dalam mendengarkan ulasan dari dosen. Szpunar et al., (2013) melaporkan dalam penelitiannya bahwa mahasiswa menghayal lebih sering pada perkuliahan daring dibandingkan ketika kuliah tatap muka. Oleh karena itu disarankan pembelajaran daring sebaiknya diselenggarakan dalam waktu tidak lama mengingat mahasiswa sulit mempertahankan konsentrasinya apabila perkuliahan daring dilaksanakan lebih dari satu jam.

Hasil penelitian juga melaporkan bahwa tidak sedikit mahasiwa yang kesulitan dalam memahami materi perkuliahan yang diberikan secara daring. Bahan ajar biasa disampaikan dalam bentuk bacaan yang tidak mudah dipahami secara menyeluruh oleh mahasiswa (Sadikin \& Hamidah, 2020). Mereka berasumsi bahwa materi dan tugas tidak cukup karena perlu penjelasan secara langsung oleh dosen.

\section{Pembelajaran daring}

Memutus mata rantai Penyebaran Covid-19 di Perguruan Tinggi Wabah Covid-19 adalah jenis wabah yang tingkat penyebarannya sangat tinggi dan cepat. Wabah ini menyerang sistem imun dan pernapasan manusia (Rothan \& Byrareddy, 2020). Pencegahan wabah ini dilakukan dengan menghindari interkasi langsung orang yang terinfeksi dengan orang-orang yang beresiko terpapar virus corona ini . Mengatur jarak dan kontak fisik yang berpeluang menyebarkan virus disebut social distancing. 
4490 Potret Model Pembelajaran Daring Online terhadap Perkuliahan Praktikum Masa Pandemi Covid-19Aulia Diana Devi, Subiyantoro

DOI : https://doi.org/10.31004/edukatif.v3i6.1490

Keberadaan dosen dan mahasiswa yang berada ditempat yang berbeda selama pembelajaran menghilangkan kontak fisik dan mampu mendorong muculnya perilaku social distancing. Menurut SteinZamir et al.,( 2020) melakukan social distancing sebagai solusi yang baik untuk mencegah penyebaran Covid19. Pelaksanaan pembelajaran daring memungkinan mahasiswa dan dosen melaksanakan perkuliahan dari rumah masing- masing. Mahasiswa dapat mengakses materi perkuliahan dan mengirim tugas yang diberikan dosen tanpa harus bertemu secara fisik di kampus. Tindakan ini bisa mengurangi timbulnya kerumunan massa di kampus seperti yang terjadi pada perkuliahan tatap muka. Organization, (2020) merekomendasi bahwa menjaga jarak dapat mencegah penularan Covid-19. Sayangnya, di daerah-daerah yang pelosok dan tidak mempunyai akses internet yang baik pelaksanaan pembelajaran daring menunjukkan kecenderungan yang berbeda. Dalam menyiasati kondisi ini, mahasiswa yang tinggal didaerah yang sinyal internet lemah akan mencari wilayah-wilayah tertentu seperti perbukitan dan wilayah kecamatan untuk dapat terjangkau oleh akses internet. Menurut Hung et al., (2010) bahwa ada beberapa catatan yang harus diperhatikan agar pembelajaran daring tetap optimal yaitu berkaitan dengan kesiapan belajar diantaranya adalah kepercayaan diri terhadap penggunaan computer/internet, pembelajaran secara mandiri, pengendalian pelajar/mahasiswa, motivasi untuk belajar, dan kepercayaan diri terhadap komunikasi secara online.

\section{KESIMPULAN}

Berdasarkan hasil penelitian dapat disimpulkan bahwa pembelajaran yang dilakukan pada masa pandemi Covid-19 di jurusan pendidikan Biologi secara keseluruhan menggunakan model daring dengan aplikasi yang digunakan berupa : Vclass, Meet Unsil, Zoom, Whatsapp, Telegram, Google Classroom, Youtube, Facebook, bahkan Messenger. Setiap dosen paling tidak menggunakan dua buah aplikasi yaitu google classroom dan whatsapp, karena dirasakan paling praktis dan minim kuota dibandingkan aplikasi lainnya. Pelaksanaan pembelajaran praktikum daring berjalan dengan lancar, namun dirasakan sebagian besar dosen dan mahasiswa kurang ideal dibandingkan pembelajaran tatap muka secara konvensional. Komunikasi terjalin kurang lancar menyebabkan materi menjadi sulit dipahami terutama mata kuliahpraktikum. Hasil belajar mahasiswa dengan pembelajaran daring bervariasi, mulai dari kurang memuaskan, cukup hingga baik.

\section{UCAPAN TERIMA KASIH}

Terinakasih Kepada LPPM Universitas HKBP Nommensen Pematangsiantar yang telah mendukung penelitian ini.

\section{DAFTAR PUSTAKA}

Agustina, I. (2020). Efektivitas Pembelajaran Matematika Secara Daring Di Era Pandemi Covid-19 Terhadap Kemampuan Berpikir Kreatif. Universitas Negeri Medan. Available At: Https://Www. Researchgate. Net/Publication/341787856_Efektivitas_Pe Mbelajaran_Matematika_Secara_Daring_Di_Era_Pan Demi_Covid-19_Terhadap_Kemampuan_Berpikir_Kreatif(Accessed: 23 April 2021).

Anggereini, E. (2017). Pengembangan E-Modul Pembelajaran Lingkungan Hidup Terintegrasi Nilai-Nilai Perilaku Pro Environmental Dengan Aplikasi 3d Pageflip Profesional Untuk Siswa Sma Sebagai Upaya Menjaga Lingkungan Hidup Berkelanjutan (Sustainable Environment). Biodik, 3(2), 81-91.

Asif, A. R., \& Rahmadi, F. A. (2017). Hubungan Tingkat Kecanduan Gadget Dengan Gangguan Emosi Dan Perilaku Remaja Usia 11-12 Tahun. Faculty Of Medicine.

Chan, N. N., Walker, C., \& Gleaves, A. (2015). An Exploration Of Students' Lived Experiences Of Using Smartphones In Diverse Learning Contexts Using A Hermeneutic Phenomenological Approach. 
4491 Potret Model Pembelajaran Daring Online terhadap Perkuliahan Praktikum Masa Pandemi Covid-19_ Aulia Diana Devi, Subiyantoro

DOI : https://doi.org/10.31004/edukatif.v3i6.1490

Computers \& Education, 82, 96-106.

Enriquez, M. A. S. (2014). Students' Perceptions On The Effectiveness Of The Use Of Edmodo As A Supplementary Tool For Learning. Dlsu Research Congress, 1-6.

Fatmawati, U. (2020). Pemahaman Covid-19 Dan Dampaknya Terhadap Proses Pembelajaran Daring Selama Pandemi Bagi Mahasiswa Prodi Farmasi Fakultas Ilmu Kesehatan Dan Sains Universitas Pgri Madiun. Prosiding Seminar Nasional Fakultas Ilmu Kesehatan Dan Sains, 1(1).

Firman, F., \& Rahayu, S. (2020). Pembelajaran Online Di Tengah Pandemi Covid-19. Indonesian Journal Of Educational Science (Ijes), 2(2), 81-89.

Gikas, J., \& Grant, M. M. (2013). Mobile Computing Devices In Higher Education: Student Perspectives On Learning With Cellphones, Smartphones \& Social Media. The Internet And Higher Education, 19, 1826.

He, W., Xu, G., \& Kruck, S. E. (2014). Online Is Education For The 21st Century. Journal Of Information Systems Education, 25(2), 101-106.

Hung, M.-L., Chou, C., Chen, C.-H., \& Own, Z.-Y. (2010). Learner Readiness For Online Learning: Scale Development And Student Perceptions. Computers \& Education, 55(3), 1080-1090.

Iftakhar, S. (2016). Google Classroom: What Works And How. Journal Of Education And Social Sciences, $3(1), 12-18$.

Indrawati, B. (2020). Tantangan Dan Peluang Pendidikan Tinggi Dalam Masa Dan Pasca Pandemi Covid-19. Jurnal Kajian Ilmiah, 1(1), 39-48.

Jamaluddin, D., Ratnasih, T., Gunawan, H., \& Paujiah, E. (2020). Pembelajaran Daring Masa Pandemik Covid-19 Pada Calon Guru: Hambatan, Solusi Dan Proyeksi. Lp2m.

Kay, R., \& Lauricella, S. (2011). Exploring The Benefits And Challenges Of Using Laptop Computers In Higher Education Classrooms: A Formative Analysis. Canadian Journal Of Learning And Technology/La Revue Canadienne De L'apprentissage Et De La Technologie, 37(1).

Kim, Y., Wang, Y., \& Oh, J. (2016). Digital Media Use And Social Engagement: How Social Media And Smartphone Use Influence Social Activities Of College Students. Cyberpsychology, Behavior, And Social Networking, 19(4), 264-269.

Korucu, A. T., \& Alkan, A. (2011). Differences Between M-Learning (Mobile Learning) And E-Learning, Basic Terminology And Usage Of M-Learning In Education. Procedia-Social And Behavioral Sciences, $15,1925-1930$.

Li, D., Zhou, Y., Li, X., \& Zhou, Z. (2016). Perceived School Climate And Adolescent Internet Addiction: The Mediating Role Of Deviant Peer Affiliation And The Moderating Role Of Effortful Control. Computers In Human Behavior, 60, 54-61.

Naserly, M. K. (2020). Implementasi Zoom, Google Classroom, Dan Whatsapp Group Dalam Mendukung Pembelajaran Daring (Online) Pada Mata Kuliah Bahasa Inggris Lanjut (Studi Kasus Pada 2 Kelas Semester 2, Jurusan Administrasi Bisnis, Fakultas Ekonomi Dan Bisnis, Universitas Bina Sa. Aksara Public, 4(2), 155-165.

Organization, W. H. (2020). Modes Of Transmission Of Virus Causing Covid-19: Implications For Ipc Precaution Recommendations: Scientific Brief, 29 March 2020. World Health Organization.

Pangondian, R. A., Santosa, P. I., \& Nugroho, E. (2019). Faktor-Faktor Yang Mempengaruhi Kesuksesan Pembelajaran Daring Dalam Revolusi Industri 4.0. Seminar Nasional Teknologi Komputer \& Sains (Sainteks), 1(1).

Rahadian, D. (2017). Teknologi Informasi Dan Komunikasi (Tik) Dan Kompetensi Teknologi Pembelajaran Untuk Pengajaran Yang Berkualitas. Teknologi Pembelajaran, 2(1).

Rhamadani, D., Maesaroh, M., \& Putri, R. (2021). Proses Pembelajaran Secara Daring Selama Pandemi. 
4492 Potret Model Pembelajaran Daring Online terhadap Perkuliahan Praktikum Masa Pandemi Covid-19Aulia Diana Devi, Subiyantoro

DOI : https://doi.org/10.31004/edukatif.v3i6.1490

Proceding Secretari Universitas Pamulang, 1(1).

Rothan, H. A., \& Byrareddy, S. N. (2020). The Epidemiology And Pathogenesis Of Coronavirus Disease (Covid-19) Outbreak. Journal Of Autoimmunity, 109, 102433.

Sadikin, A., \& Hamidah, A. (2020). Pembelajaran Daring Di Tengah Wabah Covid-19 (Online Learning In The Middle Of The Covid-19 Pandemic). Biodik, 6(2), 214-224.

Sahliah, S. (2021). Pembelajaran Pendidikan Agama Islam (Pai) Berbasis Google Classroom. Ansiru Pai: Pengembangan Profesi Guru Pendidikan Agama Islam, 5(1), 6-10.

Siddiqui, S., \& Singh, T. (2016). Social Media Its Impact With Positive And Negative Aspects. International Journal Of Computer Applications Technology And Research, 5(2), 71-75.

Silaen, S. N., \& Mulya, M. B. (2018). Density And White Shrimp Growth Pattern (Penaeus Merguiensis) In Kampung Nipah Waters Of Perbaungan North Sumatera. Iop Conference Series: Earth And Environmental Science, 130(1), 12044.

So, S. (2016). Mobile Instant Messaging Support For Teaching And Learning In Higher Education. The Internet And Higher Education, 31, 32-42.

Stein-Zamir, C., Abramson, N., Shoob, H., Libal, E., Bitan, M., Cardash, T., Cayam, R., \& Miskin, I. (2020). A Large Covid-19 Outbreak In A High School 10 Days After Schools' Reopening, Israel, May 2020. Eurosurveillance, 25(29), 2001352.

Sugiyono, S. (2010). Metode Penelitian Kuantitatif Dan Kualitatif Dan R\&D. Alfabeta Bandung.

Szpunar, K. K., Moulton, S. T., \& Schacter, D. L. (2013). Mind Wandering And Education: From The Classroom To Online Learning. Frontiers In Psychology, 4, 495.

Yandwiputra, A. R. (2020). Kuliah Jarak Jauh Karena Virus Corona, Ui: Bukan Lockdown. Tempo. Co.

Yunitasari, R., \& Hanifah, U. (2020). Pengaruh Pembelajaran Daring Terhadap Minat Belajar Siswa Pada Masa Covid 19. Edukatif: Jurnal Ilmu Pendidikan, 2(3), 232-243. 